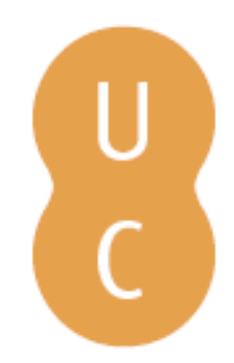

\title{
pommalina
}

\section{Social identity as a complementarity of performance and proposition (theoretical synthesis of reflexive and interactive identity)}
Autor(es):
Postoutenko, Kirill
Publicado por: Imprensa da Universidade de Coimbra
URL
persistente:
URI:http://hdl.handle.net/10316.2/31652
DOI:
DOI:http://dx.doi.org/10.14195/978-989-26-0205-9_17
Accessed : $\quad$ 26-Apr-2023 11:41:46

A navegação consulta e descarregamento dos títulos inseridos nas Bibliotecas Digitais UC Digitalis, UC Pombalina e UC Impactum, pressupõem a aceitação plena e sem reservas dos Termos e Condições de Uso destas Bibliotecas Digitais, disponíveis em https://digitalis.uc.pt/pt-pt/termos.

Conforme exposto nos referidos Termos e Condições de Uso, o descarregamento de títulos de acesso restrito requer uma licença válida de autorização devendo o utilizador aceder ao(s) documento(s) a partir de um endereço de IP da instituição detentora da supramencionada licença.

Ao utilizador é apenas permitido o descarregamento para uso pessoal, pelo que o emprego do(s) título(s) descarregado(s) para outro fim, designadamente comercial, carece de autorização do respetivo autor ou editor da obra.

Na medida em que todas as obras da UC Digitalis se encontram protegidas pelo Código do Direito de Autor e Direitos Conexos e demais legislação aplicável, toda a cópia, parcial ou total, deste documento, nos casos em que é legalmente admitida, deverá conter ou fazer-se acompanhar por este aviso.

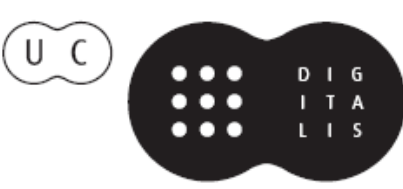


Edmundo Balsemão Pires

Burkhard Nonnenmacher

Stefan Büttner-von Stülpnagel

Editors

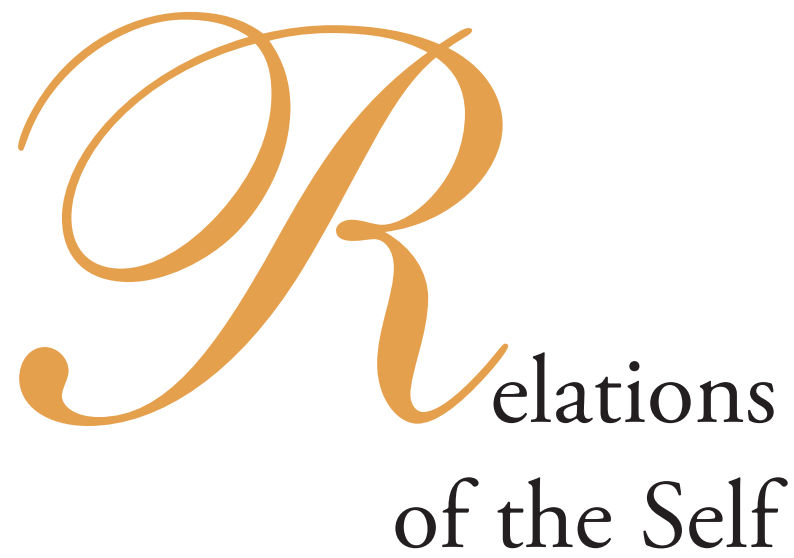


Kirill Postoutenko

Sankt-Petersburg / Konstanz

\section{SOCIAL IDENTITY AS A COMPLEMENTARITY OF PERFORMANCE AND PROPOSITION (THEORETICAL SYNTHESIS OF REFLEXIVE AND INTERACTIVE IDENTITY)}

I. Parrot and Monsieur Jourdain: Obscurity of Social Identity and Necessity of Coordination between Self-Reflexivity and Code-Reference.

In Daniel Defoe's novel The Life and Strange Suprising Adventures of Robinson Crusoe, of York, Mariner (1719) there is a handful of touching passages which put the main message of the novel - hosanna to the moral and economical individualism - into question. Indeed, even such a courageous and enterprising survivor of a shipwreck as Robinson Crusoe may occasionally feel lonely and get sentimental. Before Robinson gets acquainted with another human being on an island, his choice of conversation partners is reduced to a parrot, able (as many parrots do) to imitate human speech. It is this humble creature that moves a stern and seasoned sailor to tears:

I was so dead asleep at first, being fatigued with rowing, for part of the day, and with walking the latter part, that I did not wake thoroughly; but dozing thought I dreamed that somebody spoke to me; but as the voice continued to repeat, 'Robin Crusoe, Robin Crusoe,' at last I began to wake more perfectly, and was at first dreadfully frightened, and started up in the utmost consternation; but no sooner were my eyes open, but I saw my Poll sitting on the top of the hedge; and immediately knew that it was he that spoke to me; for just in such bemoaning language I had used to talk to him and teach him; and he had learned it so perfectly that he would sit upon my finger, and lay his bill close to my face and cry, 'Poor Robin Crusoe! Where are you? Where have you been? How came you here?' and such things as I had taught him. However, even though I knew it was the parrot, and that indeed it could be nobody else, it was a good while before I could compose myself. ${ }^{1}$

It comes as no surprise that Robinson Crusoe was relieved to hear parrot and not a human stranger waking him up: at home, domesticated alien is usually preferable to the unfamiliar conspecific. What seems to be more remarkable is the emotional outburst of the

${ }^{1}$ Daniel Defoe. The Life and Strange Suprising Adventures of Robinson Cruso (1719). - Daniel Defoe. The Novels. Vol.1. London, 2008, p. 162. 
pet owner who was perfectly aware that he was using his Poll as a dummy, a sort of natural recording device unable to decode human language. Why was Robinson so deeply touched?

It seems like Defoe's protagonist indulged in the illusion of conversation in which both sides, linguistically speaking, were "taking turns", i.e. paying attention to the other and constructing their sayings accordingly - something he sorely missed in his involuntary solitude. This illusion of understanding between a parrot and a men was created not only by the ability of a pet to replicate his owner's sayings - if that were the case, a tape recording of Robinzon's voice would have produced a similar effect, which is unlikely. Rather, it was the actual presence of a being, endowed with a similar speech apparatus (vocal chords) and a manifested ability to use it in a way noticeable to humans ("singing") which provided a fertile ground for planting the idea of mutuality. A false syllogism worked: two simple ideas of Robinson - 'I understand what I say' and 'I understand what the parrot says' lead him to believe, if only for a moment, to the symmetrical pair of beliefs - 'The parrot understands what he says' and 'The parrot understands what I say".

Astonishingly, all the four statements could be true if the criteria of mutuality is not strictly enforced. Indeed, the birds know that they sing, have a definite repertory of messages and use them purposefully (in response to their own needs or environmental circumstances). ${ }^{2}$ This means that Pell was not only saying something in Robinson' language, but was simultaneously saying something in his own language; moreover, to the extent that he was able to perceive sounds produced by Robinson, the parrot could have had his own understanding of what the latter was saying to him. Robinson Crusoe, in his turn, understood his own speech addressed to Pell, and Pell's "words" addressed to him. The fact that a parrot and a man do have some sort of conversation is due to the circumstances that 1) both recognize communication as a specialized social practice based on distal interaction and reciprocity (the parrot learns and imitates Robinson's words using the same organs as his mentor does, and Robinson listens to Pell and sheds tears) and 2) both recognize themselves as subjects (stable and active participants) in this communication. ${ }^{3}$ But the fact that precludes the real communication between a man and a parrot is not the absence of self- and other-understanding in any of them but the lack of a social mechanism which would make these understandings comparable and couple them into a single interaction practice.

Let's adjust the content of the "conversation" to the article's topic and imagine that all Robinson was saying was 'I am Robinson Crusoe' (in human language) and all his parrot was saying was 'I am Pell' (also in human language). Surprisingly, the situation would not change much. In Robinson's statement we may detect two distinct meanings of 'I' - selfreflexivity (a stable and active agency producing this saying here and now) and code-reference ('a socially accepted form of referring to all such agencies in this language). In Pell's saying,

${ }^{2}$ Lesley J. Rogers, Gisela Kaplan. Songs, Roars and Rituals: Communication in Birds, Mammals and Other Animals. Cambridge 2000, p. 72.

${ }^{3}$ Stability and activity are understood here as two general properties of living systems - which are the organizational closeness and the ability to react to the environment (see, for instance: Erich Jantsch. The SelfOrganizing Universe. Oxford, 1990, p. 29). In the current context "stability" and "activity" mean "being a separate living being" (at least for the duration of the conversation) and "being able to communicate". 
in its turn, we may detect neither self-reflexivity nor code-reference although he is certainly capable of the first and - with some limitations - of the second. ${ }^{4}$ The fact that Pell mastered the words "I am Pell" in human language does not change the situation for him. Whereas Robinson, while hearing the parrot's phrase, confirms his own code competence (his use of the word 'I' is confirmed to be correct as it is shared by another living being) and may imagine having a meaningful exchange, the poor Pell has no chance of partaking in this pleasure because his actual reference to self is expressed in a code unknown to Robinson and unrelated to the phrase 'I am Pell" in human language; in this sense, his identity among humans is not social. One level up, this asymmetry is mockingly displayed in Moliere's comedy The Bourgeois Gentlemen (1670) where a conversation between Monsieur Jourdain, an aspiring member of high society, and his philosophical teacher occurs on two communicative levels ('French' as opposed to 'other languages' and 'prose' as opposed to 'poetry'), but the awareness of the second code is only available to the more educated member of exchange. Monsieur Jourdain is genuinely surprised to have spoken prose for almost half-a century without knowing it; Pell would be no less surprised to have spoken human language to Robinson. ${ }^{5}$

The (non-)dialogue between Robinson and his parrot points at the complex nature of social identity $(S)$ : a single word - ' $I$ ' - knits together two relations of a living being - one internal (self-reflexivity [Sx]) and one external (code-reference [Sy]). ${ }^{6}$ Immediacy of this connection is irreplaceable by a simple parallelism: it would be convenient to think that parrot's actual self-awareness and the words "I am a parrot" are somehow linked, but in reality the sound combination ' $I$ uttered by parrot does not match the hypothetical ' $I$ ' of his self-reflexivity (which is not ' $I$ ' at all, of course - parrots do not use symbols in communication). On the other hand, this immediacy does not overcome the mutual impenetrability of self-reflexivity and code-reference: in a statement "I am Robinson", the reference to self as the actual speaking agency and the self-characterization by means of public discourse (such as the proper name 'Robinson') are distinctly apart from each other, although it is impossible to draw the line between one and another within the sentence. The nature of relations between two sides of social identity has been seen variously at different times and places, and the critical survey of those views $(I I-I V)$ could serve as an introduction to my own theoretical exposition of the problem $(V)$.

${ }^{4}$ See: W. John Smith. Communication in Birds. - Thomas Sebeok (ed.). How Animals Communicate. Bllomington, 1977, p. 545-574.

${ }_{5}$ "Par ma foi! il y a plus de quarante ans que je dis de la prose sans que j'en susse rien, et je vous suis le plus obligé du monde de m'avoir appris cela" ((Molière. Le Bourgeois Gentilhomme (1670) - . Molière. Euvres completes. Tome VIII. Paris, 1970, p. 292).

${ }^{6}$ This complexity alone discards the opposition between "personal" and "social" identity which is still in use in social sciences (see, for instance: Jean-Claude Deschamps, Thierry Devos. Regarding the Relationships Between Social Identity and Personal Identity. - Stephen Worchel, J. Fransisco Morales, Dario Páez, (eds.). Social Identity: International Perspectives. London, 1998, p. 1-13). 


\section{MOTTO: Social identity (S) is not a problem. Structure of $S$ : \\ $S=S x+S y ; S y \neq S x=($ non $-S) x=N x ; S=S x+N x$. \\ Relation Between Self- and Code-Reflexivity:}

Privative opposition (S vs. non-S).

\section{Special Features: Reductionism}

(either Self-Reflexivity [absolutization of performativity] or Code-Reflexivity [absolutization of propositionality]).

\section{Problems:}

Since Self- and Code-Reflexivity are not interrelated, Social Self is not social (reduction to Self-Reflexivity) or does not exist (reduction to Code-Reflexivity).

The structure of social identity outlined in the previous part $(S=S x+S y)$ is open to different interpretations. In particular, the question of degree and nature of differentiation between self-reflexivity $(S x)$ and code-reference( $S y$ ) has been hotly contested. In the most optimistic scenario, the dissimilarity between $S x$ and $S y$ is not seen as a problem that could cause their incomparability: despite the fact that two meanings of pronominal self-reference $S$ are different $(S x \neq S y)$, they could be accommodated within a single language $x(S y \neq S x=$ [non-S] $x=N x)$ or $y(S x \neq S y=[n o n-S J y=N y)$ if one of the ' $T$-s in question $(S x$ or $S y)$ is converted into the other-reference $(S=S x+N x \mathrm{v} S=S y+N y)$. In this case, the relation between self-reflexivity and code-reference loses its homonymical duplicity and turns into a privative opposition of ' $I$ and 'non-' $T$ in which just one of the markers of social identity is reflexive and therefore expressed by first-personal pronoun singular, and the other belongs to the world of objects without any special preferences.

In metaphysics of consciousness, this distinction has been sometimes literally projected onto the internal structure of personal identity: Herbert Spenser, for instance, differentiates between ego (which curbs and melts together the weaker sensations), and non-ego (which grips scattered stronger sensations outside the personality core). ${ }^{7}$ In social studies, in contrast, this contrary opposition has been usually giving way to the contradictory distinction ' $I$ ' vs. 'Other': employed by Hegel in his signature fashion (the "Other" as a negative affirmation of identity), ${ }^{8}$ it was taken up by George Herbert Mead as a quantitative difference between two states of an individual - social innocence (' $I$ ) and the height of social competence in full possession of skills needed to play every role in society ("generalized Other"). ${ }^{9}$ To interiorize this distinction, Mead also employed a second contradistinction

\footnotetext{
${ }^{7}$ Herbert Spenser. The Principles of Psychology (1873). Chicago, 2000, p. 502.

${ }^{8}$ Georg W. F. Hegel. Vorlesungen über die Philosophie der Religion (1821-1831). I. Frankfurt am Main,1996, S. 273.

${ }^{9}$ George Herbert Mead. 1927 Class Lectures in Social Psychology. - George Herbert Mead. The Individual and thje Social Self. Chicago, 1982, p. 151; George Herbert Mead. The Philosophy of the Present (1930). Chicago an London, 1982, p. 87.
} 
opposing the wildly anti-social ' $T$ - spontaneous, creative, immoral and potentially criminal - to the socially conscious ' $m e$ '. It is along these dual and trial gradations of code-reference that its utter dominance over social identity is discussed in French psychoanalysis and postpsychoanalytical thought. The structure of argument in the two most notable triangles of this kind is rather similar, albeit the details of gradations vary. Thus for Jacques Lacan the big 'Other' imprints in ' $I$ symbolic order (starting with language), ${ }^{10}$ whereas Emanuel Levinas grants to the even bigger, infinite 'Autre' the divine status defining the conditions of subjectivity per se. ${ }^{11}$ The downward projection of this 'Other' onto individual being results in creation of its smaller variant ('other'). Here the differences between psychoanalysis an humanist theology come to surface. Lacan places his 'autre' in the mirror, real or imaginary, in front of developing ' $I$ which could only achieve social maturity through identification with its own reflection. ${ }^{12}$ Levinas, in his turn, locates his finite version of 'other' next to ' $I$ ' in order to rescue it from solitary egoism: by communicating his Good to the neighbor, an individual fulfills the condition of his being-in-the-world. ${ }^{13}$ It is easy to notice that both thinkers question the relative autonomy of human self-awareness on grounds personally important to them but rather extraneous to the substance of the question: Lacan is set up to cleansie psychoanalysis from its solipsist undercurrent stemming from existentialism, and Levinas is concerned about the salvation of a human soul left to its own devices. ${ }^{14}$ This zeal perhaps explains the decisiveness with which self-reflexivity of social identity is effectively reduced to its code-reference.

No doubt Lacan and Levinas were not the first to describe social identity in a nonreflexive way. ${ }^{15}$ Indeed, their 'Autre' is a somewhat secularized form of Deity, and their

${ }^{10}$ Jacques Lacan. Le seminaire de Jacques Lacan. Livre II. Moi dans la théorie de Freud est dans la technique de psychanalyse (1954-1955). Paris, 1978, p. 275-288. The tradition of emphasizing a regulative role of symbolic system (speech or thought) in relation to the feebleness of the subject, which after Lacan flourished in post-structuralism, has a deep roots in French culture: "C'est faux de dire: Je pense : On devrait dire: On me pense" (Arthur Rimbaud. [A Letter to Georges Izambard from May 13, 1871] - Arthur Rimbaud. Euvres completes. Tome 2. Paris, 1972, p. 249). In this respect, Jacques Lacan is truer to French decadence as he is to the classical psycho-analysis where ' $I$ ' was all but passive, obedient, or helplessly irrational: in Freud's classical explication of the issue, 'Ich' mediated between the internal world of individual instincts and desires ('Es') and the socially structured world of individual ('Über-Ich') (Sigmund Freud. 'Das Ich und das Es' (1923). - Sigmund Freud. Das Ich und Das Es. Metapsychologische Schriften. Frankfurt am Main, 1992, S. 257, 267). Evidently, Freud gets quite close to the identity structure proposed by Mead, but turns around its distribution between its self- and other-referential traits - roughly speaking, 'I', Freud names ' $E s^{\prime}$ what Mead calls.

${ }^{11}$ Emmanuel Lévinas. De Dieu qui vient à l'idée. Paris, 1982, p. 121.

12 Jacques Lacan. Le stade de miroir comme formateur de la fonction du Je (1949). - Jacques Lacan. Écrits I. Paris, 1966, p. 90.

${ }^{13}$ Emanuel Levinas. Totalité et infini. Paris, 1961, p. 340-341.

${ }^{14}$ See Lacan's explicit remark on that point: "cette philosophie ne la saisit malheuresement que dans les limites d'une self-suffisance de la conscience, qui, pour être inscrite dans ses prémisses, enchaîne aux méconaissances constitutives du moi l'illusion d'autonomie où elle se confie. Jeu de l'esprit qui, pour se nourrir singulièrement d'emprunts à l'expérience analytique, culmine dans la prétention à assurer une psychanalyse existentielle (Jacques Lacan. Op. cit., p. 96).

${ }^{15}$ Luhmann calls this paradoxical form of self-identification 'other-description' (Fremdbeschreibung). Niklas Luhmann. Die Politik der Gesellschaft. Frankfurt am Main, 2000, S.320 
relation 'Other'l'other' is the most popular form of identity expression in early philosophy. ${ }^{16}$ Thus in Parmenides' The Way of Truth the Goddess is the first ever to utter 'I'; what's left to humans is a mere reiteration of her reflexive statement which - as every repetition - cannot be reflexive. ${ }^{17}$ In fact, if defining social identity among humans consists of saying ' $I$ am $X$ after the Goddess, then the only thing mortals need is the general social competence ('Goddess is the model for all humans') and a limited code-competence allowing for correct use of first-person statements in specific situations ('Goddess says 'I am $X^{\prime}$ to define its social identity $\rightarrow I$ can also use 'I am $X^{\prime}$ to define my social identity); it is evident that the unique relation between a speaker and his saying ' $I$ am $X$, which is at the core of reflexivity, plays here no role. (Later, St. Augustine managed to reclaim for humans the signifier of identity in Confessions, the word ' $P$ is said to be uttered by a human - but this change was little more than cosmetic since the actual referent of 'I-'statement was God: in this case, the reflexivity of social identity was not ignored but explicitly denied). ${ }^{18}$ However, the elaborate, masterful externalizations of ' $I$ ' performed by Lacan and Levinas were particularly good at robbing social identity of every meaning and thus carrying their reductionism to reductio ad absurdum. If ' $I$ (Sy), 'me' (N1y) and 'other' (N2y2) are all subjects of references to the higher social order ('Other' (N2y2) expressed in the same language $y$, how then is the reflexivity of $S$ expressed? It is apparent that code-reference for the purpose of self-identification is pointless precisely because it splits the person in question into two (if not three) and treats each piece as a full-blown being related to its sibling clones solely by means of social communication (common code $y$ ). This kind of bipolar disorder (for instance, Socratic "talking to self" in the place of "thinking", frequently practiced in Plato's mock dialogues) underscores the uselessness of the purely symbolic language for social identification purposes - otherwise we would have believed in Plato's bodily fission while reading his texts. ${ }^{19}$

It has been demonstrated that absolutization of code-reference in social identity destroys its core and wipes out its organizational closeness. The elimination of reflexivity in ' $I$ ' not only precipitates its breakdown into scattered social masks reflecting symbolic structure of society $(S=' I+$ ' $m e '+$ 'Other' + 'other' $+\ldots)$, but also reduces every possible identity realization to a proposition linking $S$ (as a subject) and its social function (as a predicate): in this sense, the correct way of tying the subject ' $I$ and the predicate 'philosopher' together would be not 'I am philosopher' but 'I' is 'philosopher'. It goes without saying that, expressed in this way,

${ }^{16}$ The closer one gets to social reality, the lower is the level of 'Other': for Freud, there was no principal difference between Christ and a field marshal in this respect (Sigmund Freud. Massenpsychologie und Ich-Analyse (1921). - Sigmund Freud. Massenpsychologie und Ich-analyse. Zukunft einer Illusion. Frankfurt am Main, 1993, S. 58), and in Parson's social systems theory the superego sinks to the level of a schoolteacher (Talcott Parsons. Social Structure and Personality. London, 1965, p. 141-142).

${ }^{17}$ Manfred Riedel. 'Grund und Abgrund der Subjektivität'. - Ulrich Füllerborn, Manfred Engel (eds.). Das neuzeitliche Ich in der Literatur des 18. und 20. Jahrhunderts. München, 1988, S. 32-33.

${ }^{18}$ Manfred Riedel. Op. cit., S. 47.

${ }^{19}$ See the relevant discussion: Norbert Wiley. The Semiotic Self. Chicago, 1994, p. 75. 
social identity could not be seen as an agency, let alone a stable and active one: 'I' in sentences ' $I$ ' is 'psychoanalyst' and ' $I$ ' is 'Jacques Lacan' would be a non-reflexive symbol standing for 'buman being' as a category, and there would be no reason to suppose that the 'human being $I^{\prime}$ (who is a psychoanalyst) and the 'human being 2' (who is Jacques Lacan) are the same person. ${ }^{20}$ (Obviously, the same would be true for the relation of 'I' to other code-references pertaining to social identity such as sentences ' $I$ ' is 'a person in front of a mirror' and 'other' is 'reflection of a person in front of a mirror').

Inversely, the absolutization of self-reflexivity would restore the unity of social identity by making the speaker a central part of each and every ' $I$-utterance. With the symbolic (coded) content of ' $I$ ' no longer valid, its sole meaning would be the indexical (immediate) reference to the present speaker which produces the utterance in question. In such a case, the sentences ' $I$ ' am 'psychoanalyst' / ' $I$ ' am 'Jacques Lacan' / ... ' $I$ ' am ' $Z$ ' would be much less propositions (coded descriptions) than performances (immediate indications) each time with one and only meaning - "I am this'..$^{21}$

Similar to the previously examined version of reductionism, the confinement of social identity to self-reflexivity is most often a product of polemical exaggeration. But the foundations of this one-sidedness are somewhat more solid than in the opposite case, because historical primacy and communicative inalienability of self-reflexivity in the meaning of ' $I$ ' have been suggested by linguists and semioticians since Antiquity. The view that in the development of all pronouns (including ' $T$ ), deixis (indexical, immediate pointing at the speaker) preceded anaphora (symbolic, coded affinity of the first said or written ' $I$ ' with subsequent ' $I$ 's in the same utterance) has been already put forward by Apollonius Dyskolus, the patriarch of ancient Greek grammatical science. Already by the early $20^{\text {th }}$ century this thesis was seen as confirmed - at least for the Indo-European languages - by such grammarians as Antoine Arnaud and Pierre Nicole, Wilhelm von Humboldt, Jakob Grimm and Karl Brugmann. ${ }^{22}$ In semiotics, the same idea on a broader scale was expressed much later by Charles Sanders Peirce who convincingly argued that every sign, even the one that looks like a pure symbol, contained a bit of indexicality. ${ }^{23}$ As linguistic practice shows, genealogical data of Apollonius Dyscolus and semiotic laws of Peirce work hand in hand to ensure the priority of

\footnotetext{
${ }^{20}$ Norbert Elias calls such ' $I$ '- sentences "third-person references" (Norbert Elias. Die Gesellschaft der Individuen. Frankfurt am Main, 1987, 254-255.

${ }^{21}$ The term 'performativity' has a double meaning in modern social studies: here it is used not in aesthetic sense ('performance' as opposed to 'everyday activity') but as a processual description of reality ('performing an action' as opposed to 'recording an action').

22 See summaries: Ernst Cassirer. Philosophie der symbolischen Formen. Erster Teil. Die Sprache (1923). Darmstadt, 1997, S. 209-213; Louis Marin. La Critique du discours sur la "Logique de Port-Royal " et les "Pensées " de Pascal. Paris, 1975, p. 350; Manfred Consten. Anaphorisch oder Deiktisch? Zu einem integrativen Modell domänengebundener Referenz. Tübingen, 2004, S. 1-37.

23 "An Index is a sign which refers to the Object that it denotes by virtue of being really affected by that Object. /.../ A Symbol is a sign which refers to the Object by virtue of a law, usually an association of general ideas, which operates to cause the Symbol to be interpreted as referring to that object. /.../ Now that that is being general has its being in the instances of what the symbol denotes, although we must here understand by "existent", existent in the possibly imaginary universe to which the symbol refers. The Symbol will indirectly, thorugh the association or other law, be affected by those instances; and thus the Symbol will invove a sort of Index, although an Index of a peculiar kind“ Charles S. Peirce. [Manuscript] (1902) - Charles S. Peirce.Philosophical Writings. New York, 1955, p. 102-103.
} 
performance over proposition in social identity: whenever at a certain level of language there is an ambiguity of ' $I$ ' in relation to its denotate (the speaker), another linguistic level is instantly activated to ensure the primacy of indexical meaning as opposed to its symbolic backdrop. A good example would be the oral speech: the tone of ' $I$ "points" at a familiar speaker in the darkness, the intonation sets "I want" in direct speech apart from its indirect transmission ("He said: "I want..."), and the high tone of voice differentiates self-reference in nominative ('Ich bin') from genitive ('für Ich') in a Swiss dialect of German. ${ }^{24}$

Given this remarkable functional ability of the word ' $I$ ' to always put at the forefront its indexical (performative) meaning at the expense of the symbolic (propositional) one, it comes as no surprise that the dominance of self-reflexivity in social identity has been sometimes seen as totality. In direct contrast to the reduction of the meaning of ' $I$ ' to code-reference described above, the totalization of self-reflexivity often followed the overestimation of autopoetic properties of social identity. A good example could be the revival of vitalism in the works of Hans Driesch: following both the ardent belief of early vitalists in the immanent development of an organism $a b$ ovo and the corresponding neglect of environmental factors (such as interaction), the German biologist and philosopher was expectedly inclined to limit the content of ' $I$ to its self-knowledge which could be neither objectified nor accessed by others. ${ }^{25}$ Driesch peppers Nietzschean pompous egocentric style with fashionable terminology of Bergson and Husserl, but his message points rather in the direction of radical anarchism, which major $19^{\text {th }}$ century representative Max Stirner categorically denied the role of 'Other' in the formation of ' $I$ ', and insisted on the "self-made" social identity.$^{26}$

If the simplifications of Hans Driesch and Max Stirner were (at least in part) ideologicallydriven and polemically charged, then many modern reductionist interpretations were provoked by the formidable task of differentiating self-reflexivity and code-reference within a single, noncontradictory definition of social identity. In this way, the self-referential traits of ' $I$ ' were often perceived as its sufficient characteristics: for example, in Peter Strawson's view, only one language user may ascribe to himself a certain state of consciousness without external observation, although he may use the latter if he pleases. ${ }^{27}$ (Everything seems to be correct here except for modality: a social identity worthy of a name should, not 'may', employ the external criteria of self-description (propositions): precisely such social activity as "language use" would collapse if none of the meanings of ' $I$ ' were open to external observers). Sometimes the problem

24 Karl Bühler. Sprachtheorie (1934). Stuttgart, 1999, S. 113; Elmar Seebold. Das System der Personalpronomina in den frühgermanischen Sprache. Göttingen, 1984, S. 112.

25 “'Ich weiss im Jetzt alles, was mein Selbst je hatte', - so haben wir gesagt. Nun eben diesen "alles" ist zugleich Ganzes, ist wenigstens den Bestandteilen einer vorgeschauten Ordnung zugeordnet, ob es schon ie vorgeschaute Ordnung nicht ganz erfüllt; denn das ordnungsmonistische Ideal bleibt ja "Ideal". /.../ War uns docch Ich das Einzige, das sich selbst schaut; weiss doch das Etwas-habende Ich um sein Ichwissen, (ohne dass darum das Ich als gewusstes im eigentlichen Sinne dezum Etwas, zum Reich der Gegenstände, der Objekte, gehörte” (Hans Driesch. Wissen und Denken. Prolegomenon zu aller Philosophie. Leipzig, 1919, S. 131).

${ }^{26}$ "Ich bin nur dadurch Ich, dass Ich Mich mache, d.h. dass nicht ein Anderer Mich macht, sondern Ich mein eigen Werk sein muss" (Max Stirner. Der Einzige un sein Eigentum (1845). Stuttgart, 1981, S. 256). Remarkably, this tradition still persists in psychology: Svend Brinkmann. Identity as Self-Interpretation. - Theory and Psychology, 2008 (18), No. 3, p. 404-422.

${ }^{27}$ Peter F. Strawson. Individuals: An Essay in Descriptive Metaphysics. London, 1959, p. 134. 
occurred when the semiotic mechanisms of this differentiation were ignored or suppressed in order to present the meaning of ' $I$ ' as unity: for example, in a socio-linguistic theory of Peter Mühlhäusler, Rom Harrè and Michael Freyne, which offered one of the most advanced sociological interpretations of pronominal self-reference up to date, the semiotic structure of social identity is characterized as "double indexality", although it seems obvious that the symbiosis of performance and proposition in ' $I$ ' is only possible due to the oscillation of its meaning between an index and a symbol. ${ }^{28}$ In other cases the ascription of internal semantic coherence to markers of social identity is caused by the desire to create a consistent grammatical classification. For instance, in classical semantic theory, a pronoun (say, ' $I$ ) only "refers" to the specific object whereas a noun (say, 'linguist') "denotes" a class of objects. This contradistinction raised in the last decades a lot of questions: as it turns out ' $T$ undoubtedly does refer to the present speaker (as an indexical sign), but it also denotes the class of human beings (as a symbolic sign). ${ }^{29}$ In this sense the assignment of the marker of social identity to a single grammatical category appears to be as improbable as a harmonization of its relation to the signified (speaker) or the unification of its function in social communication. Depending on the perspective, ' $I$ ' happens to be a pronoun or a noun, an index or a symbol, a performance or a proposition, and this duplicity cannot be eliminated entirely on any level: for any said or written 'I am $N$, its nominal (anaphoric) semantics (' $I$ ' referring to the speaker's ' $I$ in previous such proposition) makes no sense if not predated by the pronominal (deictic) one (' $I$ pointing at the speaker's body); its symbolic meaning (' $I$ as a socially acceptable form of individual selfreference) will remain a pure abstraction apart from its meaning as index ('I' as an actual reference to a physically present living being); and, lastly, its performance (' $I$ as an action performed by its referent's hand or mouth) will only partake in communication if complemented by a proposition (' $I$ ' as a subject which relation to predicate ' $N$ is perceived by all interaction participants similarly regardless of interactional setting). ${ }^{30}$ To make things worse, the perspectival heterogeneity of pairs radiating from ' $I$ ' (pronoun - index - performance $v$ s. noun symbol - proposition) complicates the consolidation of oppositions into triads: the further outward one goes, the less possible it is to sustain a common principium divisionis for the pairs pronoun-noun, index-symbol and (especially) performance-proposition. ${ }^{31}$

\footnotetext{
${ }^{28}$ Peter Mühlhäusler, Rom Harrè, Michael Freyne. Pronouns and People: The Linguistic Construction of Social and Personal Identity. Oxford, 1990, p. 88, 93, 95, 97.

${ }^{29}$ See, for instance: Roland Hausser. A New Treatment of Model in Context Theory. - Sull'Anaphora. Atti del Seminario Accademia della Crusca. Firenze, 1981, p. 168.

${ }^{30}$ On the uniqueness of the word 'I' in this sense see: Roderick Chisholm. The First Person: An Essay on Reference and Intentionality. Minneapolis, 1981, p. 47; Ксения Майтинская. Местоимения в языках разных систем. М., 1969, c. 141; Anthony Kenny. The First Person. - Jenny Teichman, Cora Diamond (eds.) Intention and Intentionality. Sussex, 1979, p.13; (For the last opposition, see the exemplary case study of Cartesian cogito ergo sum: Jaakko Hintikka. 'Cogito, Ergo Sum: Inference or Performance?' - The Philosophical Review, Vol. 71, No. 1. (Jan., 1962), pp. 3-32; Jaakko Hintikka. 'Cogito, Ergo Sum as an Inference and a Performance'. - The Philosophical Review, Vol. 72, No. 4. (Oct., 1963), pp. 487-496).

${ }^{31}$ Otto Jespersen tried to decouple semiotics from grammar entirely by trying to prove that not only a pronoun, but a noun as well could be an index: in his view, Jack referring to himself as 'Jack' would have the same social identity as Jack referring to himself as ' $I$ ((Otto Jespresen. Language: Its Nature, Development and Origins. London, 1922, p. 123). In my view, the Danish linguist overstated his case: the variety of social settings in which the use of Jack as a self-reflexive form is probable does not really go beyond two most typical scenarios - discursive
} 
This multifaceted duplicity, it seems, dashes all the hopes for the unified "language of individuality" able to fully communicate one's self-reference to other living beings: at the turn of the $20^{\text {th }}$ century, this frustration found a sublime form of mathematical abstraction which effectively put an end to the reductionist utopia of a single language of identity. The hope for an absolute individual expression fell apart because its code-reference was incompatible with self-reflexivity. In a similar way, the perfect language, free of lies and contradictions, had no place for self-referencial constructions which would have compromised its consistency without proving its veracity: Bertrand Russell and Alfred Whitehead banned reflexive statements from their "pure mathematics" altogether, and Alfred Tarsky later stipulated that for every language $x$ the truthfulness of its meanings could not be defined but in another language $y .{ }^{32}$

Correspondingly, these findings proved the impossibility of defining the social meaning of anything (identity included) in a reductionist way $(S=S x+N x)$. But failed attempts to express social identity in a single language, had fruitful implications. The view of social identity as antinomy did not break it up; on the contrary, it allowed for crucial refinement of its fundamental contradistinctions (described in III) and thus created presuppositions for the future synthesis (outlined in $I V$ ).

\section{Social Identity as Antinomy: Negative Dialectics of Sub-Identities.}

MOTTO: Social Identity $(S)$ is a problem with no solution.

Structure of $S$ :

$S=S x+S y ; S y \neq S x \neq N x$.

Relation Between Self- and Code-Reference:

Antinomy ( $S x$ vs. Sy).

Special Features: Dualism

(synthesis of Sub-Identities $S x$ and $S y$ is impossible).

\section{Problems:}

Since Self-Reflexivity and Code-Reference are connected dogmatically, the unity of Social Self remains unexplained.

The conflict between the unconditional unity of social identity $(S=S x+S y)$ and its unbridled heterogeneity $(S y \neq S \mathrm{x} \neq N x)$ runs deeper than its obvious solutions. Unlike Zeno's apories, it's not a mere miscalculation or a logical mistake: as one could see in the previous part, any attempt to "normalize" $S$ by clearly separating its one and only self-

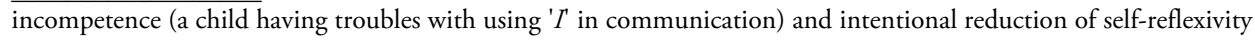
due to semantic or pragmatic reasons ('As always, Jack will take care of everything '). It is hard to believe that the last expression, which simulates the perspective of the recipient in order to appeal to his conscience, is self-referential to the same degree as a habitual 'I will take care of everything'.

32 Bertrand Russell, Alfred Whitehead. Principia Mathematica. Vol.1 (1910). Cambridge, 1978, p. 61; Alfred Tarski. The Concept of Truth in Formalized Languages (1935) - Alfred Tarsky. Logic, Semantics, Metamathematics. Indianapolis, 1983, p. 265; Kurt Gödel. Über formal unentscheidbare Sätze der Principia Mathematica und verwandter Systeme I. - Monatshefte für Mathematik und Physik 38 (1931), S. 173-198. 
referential part (' $I$ ) from many other-referential parts ('Other', 'other' etc.) backfires and puts into question the very integrity of $S$ it was supposed to uphold. Nor is it an antinomy in the classical Kantian sense because, for the same reason of its irreducibility to a single language, social identity cannot be expressed as a simple contrary opposition $(S=S x+S y=$ $S x+\neg S x)$. If anything, the $S$ tried out by Schelling and many others brings to mind the negative dialectics of Theodor Adorno, where the classical concept of a thing is opposed to its immediate givenness - a non-identical, absolute individuality which relates to observer by contacting, affecting, irritating him. ${ }^{33}$ It is apparent that such a controversy, which, needless to say, resists reconciliation, contains the seeds of all the internal differentiations of identity discussed before: distal communication (Symbol) vs. immediate contact (Index), conceptual generality of a pronoun (Noun) vs. absolute individuality of its denotate (Pronoun), even notion (proposition) vs. action (Performance). However, for all his obvious differences with Kant, Adorno, too, readily admits insolvable contradictions into cognition, which makes his late doctrine a relevant philosophical framework for the discussion of social identity in this part. ${ }^{34}$

If for that matter one looks at the discussion around ' $I$ ' in Kant's writings, one is struck by the intensity of antinomical thinking at work: the unity of self is stated as ferociously as its homogeneity denied. Responding to the imaginary claim that homo sapiens may not remain the same human being in all its states, Kant even loses his temper, calling the question of his imaginary adversary "incongruous": in his view, the formal (presentational) duplicity and contradictoriness of ' $I$ ' should not be taken for its material (content-based) doubleness. ${ }^{35}$ This unequivocal message does not so much defend the unity of consciousness as it underscores the necessity of at least two languages (modes of presentation) for describing identity of a single person. Indeed, the interrelations between the respective facets of identity $S x$ and $S y$, summarized below, appear to be relatively regular, but it does not mean that specific linguistic, semiotic and interactional properties of these languages $x$ and $y$ are always clear and straightforward.

As a part of speech, $S x$ (which is on various occasions called ' $I$ ' of cogito', 'simple ' $T$, 'reflective 'I', ' $I$ ' of pure thinking' and ' $I$ ' of apperception') presents a mixture of various pronominal and nominal properties. Like a noun, it is interchangeable with nouns (like 'Thing') and nonreflexive pronouns (like ' $H e^{\prime}$ or ' $\left.I t\right){ }^{36}{ }^{36}$ similar to a pronoun, it combines (apart from one another) code-reference (' $I$ as a pure category, a general notion of self, an empty superficial form for the subject's thoughts, a simple understanding of 'I' in its relation to others which makes collective identity possible) and self-reflexivity ('I' being present in all the thoughts of the subject, identical to itself, reflective, never being a predicate of another subject). ${ }^{37}$ As a sign, $S x$ appears to serve on

${ }^{33}$ See: Theodor W. Adorno. Negative Dialektik. Frankfurt am Main, 1966, S. 160-163.

${ }^{34}$ This also explains why Hegelian "positive dialectics" is so rarely invoked in this text. .

35 Immanuel Kant. Anthropologie in pragmatischer Hinsicht (1798). - Immanuel Kant. Werkausgabe. Band 12. Frankfurt am Main, 1995, S. 417 (hereafter referred to as $A p H$ ).

${ }^{36}$ Immanuel Kant. Kritik der reinen Vernunft (1781). - Immanuel Kant. Werkausgabe. Band 4. Frankfurt am Main, 1995, S. 344 (hereafter referred to as $K r V-2$ ). Hegel takes over this elimination of reflexiviity in ' $T$ ', equating it at one point to 'it' (Georg W. F. Hegel Wissenschaft der Logik. Band 1 (1812). Frankfurt am Main, 1986, S.489).

${ }^{37}$ Examples of code-reference of 'I' are taken from: Immanuel Kant. Kritik der reinen Vernunft (1781). Immanuel Kant. Werkausgabe. Band 3. Frankfurt am Main, 1995, S. 138; 174 (hereafter referred to as $\mathrm{KrV}-1$ ); $K r V-2$, S. 346, 362, 363, 367. For examples of self-reflexivity of ' $I$ see: $K r V-2$, S. 346, 363; ApH, S. 417, 427, 430. 
most occasions as a symbol, being in this sense a formal, rational, abstract, discursive 'I' which concrete denotate is manifestly unimportant. ${ }^{38}$ In this sense it may be perhaps called a symbol of a symbol, a sign of a second degree that creates a reflexive loop not by denoting its generalized human signified ('each and every speaker is able to say $I$ ) but by referring to the pure grammatical category of first-person personal pronoun: at least, some hints of this emancipation are unmistakable in the Critique of Pure Reason. Some denotative properties of $S x$ listed by Kant (for instance, 'being homogeneous' or 'always having the same meaning') could be in principle attributed to both the symbolical and the indexical relation between the signified and the signified, but my guess is that Kant's implicit preference would be symbol since for him the homogeneity and stability of $S x$ is not an empirical given of immediate experience, but a product of apperception carried out by pre-established formal (coded) rules common for all. ${ }^{39}$ Lastly, as a form of interaction, $S x$ is mostly proposition, being typically given a shape of a preformed proposition ('I am simple' / 'I am a substance), or - if occasionally referred to as activity ('I think) - analyzed from the standpoint of its structure. ${ }^{40}$ Still, this stiff construction is occasionally animated and portrayed as performance of $S$, albeit the one of an entirelly intellectual (non-experiential) kind - such as "pure reflection" or "apperception" ${ }^{41}$.

The language $y$ that constitutes the second part of the "formal doubleness of ' $I$ " in Kant's philosophy, is much more equivocal, elusive and reliant on its counterpart than the language $x$. Named in different cases as 'self-observation', 'I of apprehension', 'internal subject', 'subject-in-itself', 'I as I appear to myself', 'subject of the inner', it has uncertain contours, few stable properties and looks at times like a shadow of its alter ego, despite its multiple connotations of 'realness'. ${ }^{42}$ Indeed, in terms of grammar $S y$, like a bindweed, depends on the elaborate structural framework of $x$. In particular, as a noun it often plays the role of a predicate to the subject $S x$ in formulations like 'object of thought' or the exact negation of its well-structured ('homogeneous') opposite ('givenness of heterogeneity'), and as a pronoun it appears at times to be hermetically sealed in its reflexivity by the postfix an-sich ('subject-initself', 'I as an object-for-itself', 'human being-in-itself). ${ }^{43}$ In semiotic terms, Sy gravitates towards being an index since it links ' $I$ to its denotate in the process of immediate (apparently visual) contact - Kant uses the terms 'empirical', 'concrete' and 'material'.44 Ironically, Sy has its most conspicuous presence in $S$ as a form of interaction, namely performance, which is usually shown as directed towards the essence of social identity, be it 'perception'. 'observation', 'apprehension', 'internal experience of the material, 'intuitive apperception'. ${ }^{45}$ It seems clear that the irrational, sensual nature of all these activities precludes their easy verbalization in terms of the 'perfect language' $S x$. But this sad truth does not come as a surprise to Kant, and his ultimate overview of the relations between $S x$ and $S y$ mixes insight with sobriety.

${ }^{38} \mathrm{KrV}-2$, S. 363; $A$ pH, S. 427, 430, 432.

${ }^{39}$ On homogeneity and semantic stability of $S x$ see $K r V-1,138 ; K r V, 346,366$; On apperception of ' $I$ see $K r V-1$, S. 138; KrV-2, S. 346, 397; ApH S. 430, 432.

${ }^{40} \mathrm{KrV}-2$, S. 366, 367, 384; ApH, S. 430.

${ }^{41}$ ApH 417, S. 430.

${ }^{42} K r V-1$, S. 138, 151-152; KrV-2, S.346, 366.

${ }^{43} K r V-2$, S. 363; ApH, S. 427.

${ }^{44} K r V-2$, S. 359, 367;ApH, S. 417, 427, 430, 432.

${ }^{45} K r V-1$, S. 151-152; KrV-2, S. 346, 359, 363; ApH, S. 43-432. 
The alluring opacity of $S y$, the manifest asymmetry between its boundless signified and the wanting signifier creates a second type of relation between the ' $I$ of cogito' and the ' $I$ of experience': parallel to being a kind of personal identity in its own right, the eloquent but vacuous $S x$ becomes a signified for the pregnant but mute $S y$. But this attempted hierarchy between two facets of personal identity is seriously complicated from the start. On the one hand, the "real" perception of internal self, being sensible, does not really come to surface but in appearances incompatible with the rational, abstract meaning of cogito; on the other hand, the form of rational ' $T$ making judgments (including its unity) is developed in advance and cannot be influenced by experience produced by the intuitive 'I'. As a result, the human being appears to itself not the way it "really" is to itself, and Kant is cautious enough to stipulate that $S x$ does not "represent" $S y$ (as a symbol), but merely "refers" to it in a nonrepresentational way (as an index). ${ }^{46}$

This reservation is by no means a saving-face euphemism intended to keep $S$ together at any price; rather, Kant's carefully weighed skepticism puts the discussion of systemic complexity within social identity on a new level. Similar to the old cog-wheels that occasionally idle, the unity of the rational and the empirical ' $I$ in Kantian philosophy sometimes falls apart and starts doubling its functions. As has been said before, self-reflexivity of $S x$ at times loses its touch with an empirical subject and starts spinning around its empty code-reference, endlessly refining its homogeneity (self-identity of thinking subject as a pure, increasingly impeccable logical form) and fine-tuning its operational properties (such as definition-giving or conceptforming in the process of cognition). In its turn, the $S y$, which is also self-identical (i.e. empirically given to its bearer) but cannot communicate its substantiality outwards, begins an equally closed, if invisible, circuit of its infallible perceptual content. ${ }^{47}$ At such unlucky moments, the representational duplicity of Kantian $S$ fails: $S x$ has nothing but words, and $S y$ has everything but words.

Importantly, these centrifugal tendencies within $S$ survived in neo-Kantianism (where such black holes as "thing in itself" were sealed up) and in analytic philosophy: for instance, such diverse thinkers as Rickert and Wittgenstein held ' $I$ ' to have something that could not be fully objectified. ${ }^{48}$ What's more, they outlived critical philosophy in general: even in a pragmatist

${ }^{46} \mathrm{KrV}-2$, S. 205, 367.

${ }^{47}$ The long quotatoin illustrates the scale of the problem in Kant's own words" Der Satz aber, ich denke, so fern er so viel sagt, als: ich existiere denkend, ist nicht blosse logische Funktion, sondetrn bestimmet das Subjekt (welches denn zugleich Objekt ist) in Ansehung der Existenz, und kann ohne den inneren Sinn nicht stattfinden, dessen Anschauun jederzeit das Objekt nicht als ding an sich selbst, sondern bloß als Erscheinung an die Hand gibt.In ihm ist also schon nicht mehr bloße Spontaneität des denkens, sondern auch Rezeptivität der Anschauung, d. i. das Denken meiner Selbst auf die empirische Anschauung eben desselben Subjekts angewandt. In dieser letzteren müsste den nun das denkende Selbst die Bedingungen des Gebrauchs seiner logischen Funktionen zu Kategorien der Substanz, der Ursache etc. suchen, um sich als Objekt an sich selbst nicht bloß durch das Ich zu bezeichnen, sondern auch die Art seines daseins zu bestimmen, d. i. Sich als Noumenonzu erkennen, welches aber unmöglich ist, indem die innere empirische Anschauung sinnlich ist, und nichts als Data der Erscheinung an die Hand gibt, die dem Objekte des reinen Bewusstseins zur Kenntnis seiner abgesonderten Existenyz nichts liefern, sondern bloß der Erfahrung zur Behufe dienen kann." (KrV-2, S. 360)

${ }^{48}$ See: "Es gibt etwas, das nicht Objekt ist: Ich bin. Das ist zweifellos, und das Wort "Ich" bedeutet in diesem satz, den jeder versteht, nicht nur etwas, das auch Objekt werden kann” (Heinrich Rickert. Der Gegenstand der Erkenntnis. Tübingen, 1928, S. 37). Wittgenstein's argument goes along the same lines (see summary: Wolfgang 
epistemology of Donald Davidson there is a sharp break between the code-reference (a conceptual knowledge of self acquired in interpersonal communication, fallible but understandable to others) and self-reflexivity (a perceptual self-knowledge containing beliefs, wishes and fears, available to its owner only and generally infallible).$^{49}$ Davidson appropriately calls $S x$ 'the third-person authority' and Sy 'the first-person authority', hinting at the respective semantic properties of ' $I$ ' (being a noun vs. being a pronoun), but his examples are even more telling than his categorizations. Indeed, the possibility of translation between the language $y$ (' $I$ have a certain sensation on my skin') and the language $x$ ('I have a sunburn') certainly exists, and amability to perform such translations is generally expected from a holder of a social identity, but the content of $S$ would never depend on whether such a translation was exact, honest, instant or complete. Simply speaking, the sentence "I have a sunburn" will not identify any social identity unless complemented by the reflexive reference of its utterer to his state, but the form of this reflexivity it is profoundly unimportant: for a medical doctor (and society in general), an answer to the question "Is there a sunburned person in this room?" should not be clear, positive or informative (doctors know better) but should be reflexive (if someone is not alive in a way obvious to others, he cannot be an object of medicine, even if he uttered 'I am sunburned' a minute ago)..$^{50}$ All in all, there is no opportunity to present the connection between $S x$ and $S y$ as the relation of two propositions, because the reflexive facet of social identity stubbornly resists definition in grammatical or logical terms, lurking in the depth of the word ' $I$ but refusing to partake in its verbal semantics.

But the revision of a "double-proposition-hypothesis" started already during Kant's lifetime: transcendental idealists (and later Hegel) set out to make the ruptures of ' $I$ more predictable and constructive by offering a positive teleology of ' $I$-in-motion, which in practice meant increasing mobility, flexibility and coordination of the opposites within the conceptual system. The mobility growth was achieved by making performance a general modus operandi of both $S x$ and $S y$ : Fichte and Schelling were tireless in emphasizing the moving, in-becoming, tentative nature of self as a whole at all the moments of its existence. ${ }^{51}$ This universal (and

H. Schrader. 'Überlegungen zur sprachanalytischen und transzendentalphilosophischen Ich-Theorie'. - Klaus Hammacher (ed.). Der transzendentale Gedanke. Hamburg, 1981, S. 112).

49 Donald Davidson. Subjective, Intersubjective, Objective. Oxford, 2001, p. XVII, 34-35, 193. The consequences of this break for the social study of personal identity have been analyzed in formal sociology: Leopold von Wiese. Die Philosophie der persönlichen Fürwörter. Tübingen, 1965, S. 15.

50 This social necessity correlates with the internal view of identity which combines a "general epistemic consciousness" expressed in symbolic terms and more available to the society than to its subject ("I am 180 centimeters tall") with the "immediate epistemic consciousness" ("I am in this state") open (due to the indexical meaning of the deictic term "this") to the speaker only (Ernst Tugendhat. Selbstbewusstsein und Selbstbestimmung. Frankfurt am Main, 1979, S.27-28)

51 "Das Ich ist unaufhörlich im Werden, es gibt in ihm gar nichts dauerndes" (Johann Gottlieb Fichte. Grundlage des Naturrechts nach Prinzipien der Wissenschaftslehre (1796). Hamburg, 1979, S. 28 (hereafter referred to as GN); "Ich ist nichts als Tätigkeit" (F.W.J. Schelling. System des transzendentalen Idealismus (1800). Hamburg, 1992, S.74 (hereafter referred to as $S t I$ ). Compare Hegel's definition of ' $I$ ' in similar performative terms: ”Jene erste Reflexion aus der Unmittelbarkeit ist das Sichunterscheiden des Subjekts von seiner Substanz oder der sich 
positive) correlation between the meaning of $S$ and its systemic development is manifest in Schelling formula "self = time thought of in action" and in a clear downgrading of proposition as a form of identity expression. ${ }^{52}$ The preference given to performance in the structure of $S$ appears at different levels. At times it is relative: 'practical 'T', compared to its respective antecedents, has the upper hand in both doctrines, and performativity of 'I' serves as a marked pole of its internal oppositions such as 'acting' / 'acted upon' (Fichte), or 'observing' / 'being observed' (Schelling). ${ }^{53}$ At other times it is absolute: the relation 'subject'l'object' is described as procedure (rather than a proposition), and the concept of activity serves as a common ground rather then differential in Schelling's oppositions 'limited activity' / 'activity that crossed the limit', or 'real activity' vs. 'ideal activity' or in Fichte's opposition 'observing / self-observing'. ${ }^{4}$ More importantly, it allows for recasting the antinomy $S x / S y$ into a dialectical contradiction and thus moves towards an even more systemic, dynamic, integrated view of social identity. For instance, the grammatical complexity of ' $I$ ' is presented in transcendental idealism in a much more balanced and convincing way than in earlier philosophies. The list of nouns synonyms of ' $I$ in Fichte's texts is much longer than in Kant's writings (it includes being', 'life', 'unity', 'immanence', 'reason', 'world' and even 'light' - a popular visual metaphor), but this breadth of nominal meaning does not threaten the pronominal semantics of $S$, because the opposition between self-reflexivity of ' $I$ ' and its code-reference is so centrally placed and firmly anchored in Fichte's teleology of self that it cannot be knocked off balance by any formally admissible prolongation of this synonymic chain. ${ }^{55}$ In reality, the relation between the ' $I^{\prime}$ identical to itself and the ' 'I' non-identical to itself' both in Fichte and in Schelling is sealed by the fact that $S x$ and $S y$, unavailable to each other, try hard to become one and fail - because in such a case the subject will cognize itself in toto as an object, complete its development and stop living (or "become a dead nature", as Schelling puts it). ${ }^{56}$ As the fulfillment of utopia destroys history and returns its agents to the original state of innocence, the full objectification of subject would bring $S$ back to the impenetrable proto-existence of the 'I'-in-itself', which deconstruction was a matter of honor for transcendental idealists. ${ }^{57}$

The major contribution of Fichte and Schelling to the (future) theory of social identity was not limited to 'performative turn' or even explicit applications of their analyses to the world of human beings (particularly Fichte was prone to see his sophisticated 'I' as belonging to the "individual person of everyone" in society). ${ }^{58}$ Rather, the most important breakthrough

entzweiende Begriff, das Insichgehen und werden des reinen Ich.” (Georg W. F. Hegel. Phänomenologie des Geistes (1807).Frankfurt am Main, 1979, S. 588).

52 StI, S. 138.

${ }^{53}$ GN, S.1;StI, S. 72;

54 StI, S. 89, 92; GN, S.1.

55 Johann Gottlieb Fichte. Die Wissenschaftslehre. Zweiter Vortrag im Jahre 1804. Hamburg, 1986, S. 234, 239, 270 (hereafter referred to as $W L$ ).

${ }^{56}$ StI, S. 69.

${ }^{57}$ StI, S. 172; see also: Johann Gottlieb Fichte. Die Bestimmung des Menschen (1800). Hamburg, 2000, S. 80.

${ }^{58}$ Fichte, at any rate, saw in his 'I' more than just an an empty code-reference, defining it at one occasion as an "individual person of everyone" (WL, S. 136). See also as a reverse definition of a person as a certain material ' $I$ ( $G N$, S. 57). This makes a remarkable difference to Kant who ruled out the use of 'I' in sensu latiori ("The whole human with body and soul") in his philosophy (see the survey: Tobias Rosefeldt. Das logische Ich. Berlin, 2000, S. 14). 
was the recognition of the fact that no plausible relation between self-referential traits and intersubjective connotations in the meaning of ' $I$ may be expressed in less than two different languages. Unlike the armchair division of two representational modes within $S$ in Kantian philosophy (which leaves the conceptual and representative dominance of cogito intact), the essence of social identity of transcendental idealists consists in an actual hovering (Schweben) over the incompatible perspectives of "limiting activity" of observing $S x$ and "limited activity" of observed Sy (Schelling), or - less-explicitly - between the ' $I$ of Absolute Reason and the 'I' of its subsequent objectification (Fichte). ${ }^{59}$ In respect to this smart correlation between the shifting function of 'I' in $S$ and the corresponding changes from $x$ to $y$ and back, Husserl's attempts to ascribe the free movement between $S x$ and Sy to a single, unchangeable, formally (grammatically) unified ' $I$ '-agency seems to be a step back, and Adorno's wrath in this relation is not unfounded. ${ }^{60}$

Nevertheless, the difficulties with translating the heritage of Fichte and Schelling into the language of sociology are apparent. The biggest problem, in my opinion, stems from the idealist presuppositions of their philosophies. If the human body, in order to exist, needs to be "ascribed to" (or "seen by") ' $I$ and turns - as a result of this 'ascription' (or 'seeing') - to its 'seen', or 'representative' in the sensual world; if all action is attributed to the 'seeing ' $T$ ' (or even 'absolutely formal ' $T$ ') and the 'material ' $T$ ', notwithstanding its grand name, remains an inert 'predicate of the logical subject', an externally 'closed articulated whole' (as Fichte implies), then the only form of performance available to humans is intellectual or spiritual activity. ${ }^{61}$ Such "performance" may in principle have an infinite number of steps in its asymptotic approximation to the absolute self-reflexivity (I see that (I see that (I see that $(I$ see... $)))$ ), but it has very little relation to the social world where ' $I$ should be uttered, body should be seen and identity has to be recognized. ${ }^{62}$ True, in such a world, as Pierre Gassendi was able to demonstrate two and a half centuries before Fichte and Schelling, the relation between $S x$ and $S y$ in all its complexity is perfectly presentable on the level of immediate perception: ' $I$ acting' and ' $I$ ' acted upon', 'subject observing' and 'subject observed' cannot coincide simply because human eyes looking at their owner cannot see themselves in the moment of seeing. ${ }^{63}$

\footnotetext{
59 StI, S.89; WL, S. 278-279.
}

60 "Die beiden zugleich vorhandenen Welten [the "natural" and the "arithmetical" one - K.P.] sind ausser Zusammenhang, abgesehen von ihrer Ichbeziehung, der gemass ich frei meinen Blick und meine Akte in die eine und andere hineinlenken kann”. (Edmund Husserl. Gesammelte Schriften. Bd. 5. Ideen zu einer Reinen Phänomenologie und phänomenologischen Philosophie (1913). Hamburg, 1992, S. 60). It should be noted that the bulk of Adorno's criticism was directed against the later writings of Husserl (Theodor W. Adorno. Zur Metakritik der Erkenntnistheorie (1956). Frankfurt am Main, 1990. S. 226-229). However, one of his main doubts - that an abstractly defined ' $I$ ', cut off from senses and intellect, can unify consciousness - stands for this text as well: it is hard to understand is how ' $I$ '-relation remains the same while its owner switches from one perspective to another and what in this case its meaning is except for the simplest code-reference (the homonymy of ' $I$ 's).

${ }^{61}$ GN, S. 57.

${ }^{62}$ See the formulaic description of this infinity: Luis Mateus Rocha. 'Eigenbehavior an Symbols'. - Systems Research, Vol. 13, No.3, p. 371. The decisive step from inner ' $I$ ' to its social incarnation is made by Hegel for whom the discussion of the unspoken pure ' $I$ makes no sense (Georg W. F. Hegel. Phänomenologie des Geistes (1807). Frankfurt am Main, 1996, S. 376).

63 This passage together with the highly valuable discussion is taken from Victor I. Stoichita's book (Das selbstbewusste Bild. Vom Ursprung der Metamalerei. München, 1998. S. 225). Centuries before Gassendi, François 
And one could offer (as Gassendi did) - reflection in a mirror - as an empirical correlate to the indirect reconciliation of two perspectives of ' $I$ from the next-level standpoint, envisioned by transcendental idealists in the soaring heights. Lastly, one may even argue (as Gassendi did not, but Goethe did) that an infinite number of mirrors reflecting each other on both sides of the body could create an ascending linear teleology of ever-improving self-perception similar to the ones imagined in the realm of thought, feeling and imagination by Fichte and Schelling. ${ }^{64}$

But that's where the parallelism stops. Although developmental psychology states that two levels of self-reflexivity ('I am smart because I can do many things') is a minimum expected from a mature adult, one mirror is usually enough for the purpose of self-recognition. ${ }^{65}$ Even if the multilevel performance of ' $I$ ' described by Fichte and Schelling took place in the social world (i.e. were expressed verbally), it would be nothing but a pair of propositions within $S x$, linked to each other both internally (as a code-reference of ${ }^{\prime} I^{\prime}(1)$ and ' $I^{\prime}(2)$, based on the symbolic meaning of ' $I$ and borrowed (internalized) from the social communication), and externally (as a self-reflexivity of the speaker, expressed through the indexical meaning of ' $I$ but not available in these sentences). It seems therefore evident that the relations within the pair ' $I(1)$ and ' $I$ '(2) are nothing but a very good one-dimensional (i.e. monolingual) representation of relations between two parts of $S$, which, as it is always the case with images, schemes and models, cannot serve as a real thing - the actual performance of social identity is just not there. So it turns out that double-performance reconstruction of the architecture of ' $I$ ' in the works of Fichte and Schelling, being extremely productive in details and (mostly negative) conclusions, has been a thinly veiled version of the double-proposition explication of $S$ which has already been shown to be incompatible with the conditions of social world. Ultimately, there seems to be no way around theories that from the outset present social identity as a synthesis of performance and proposition. The problem of many of such theories is their tentativeness, generality and lack of dynamics which makes them an unfavorable contrast to the masterful designs of Fichte and Schelling.

The very possibility of internal heterogeneity within $S$ that goes beyond the limits of language has often been acknowledged with some reluctance. It has been often suggested indirectly by ascribing such semiotic or pragmatic properties to $S x$ that $S y$ would be considered as standing outside of language: usually, the boundary would go between the hypertrophied communicability of one (imposed by society) and the extreme immediacy of the other (developed from within). The pragmatic criteria for this distinction were used, for

\footnotetext{
Villon played out the same problem in a narrative form: in his idiosyncratic Ballade (1450) each stanza consisting of monotonous boasting ("Je congnois bien mouches en let // Je congnois a la robe l'homme, // Je congnois le beau temps du let..." etc.) ends with the disarming suggestion: "Je congnois tout, fors que moy mesmes"(François Villon. (Euvres. Moscou, 1984, p. 264)

${ }^{64}$ See J. W. Goethe. Wiederholte Spiegelungen (1823). - J. W. Goethe. Sämtliche Werke. Band 14. München, 1986, S. 64.

${ }^{65}$ The example is taken from: Andreas Demetriou. Organization and Development of Self-Understanding and Self-regulation: Towards a General Theory. Monique Boekaerts, Paul R. Pintrich, Moshe Zeidner (eds.). Handbook of Self-Regulation. San Diego, 2000, p. 232-233.
} 
instance, by Henry Bergson who subdivided social identity into a 'superficial, reflective, symbolically represented, conventional 'T' (common for many people) and 'fundamental, internal, real, concrete ' $I$ ' (specific for just one human being): here the circumstantial properties of $S y$ being original, unique for each person, not covered by the conventions of human communication - effectively push it on the brink of coded interaction, although the possibility of its being an index is not ruled out entirely. ${ }^{66}$ This method of differentiating between $S x$ and $S y$ from the standpoint of codified social norms (language being one of them) has left its traces in early sociological theories of social identity: Georg Simmel, for instance, described the formation of societal 'I' as the gradual and uncertain rapprochement between the individual self (non-identifiable by others) and the objectively-formed subjectivity (ascribed to the individual). ${ }^{67}$ Furthermore, the view of Bergson and Simmel has been advanced in the cultural anthropology of Jan Assman, where the 'individual ' $T$ (original and irreducible, developed under the guidance of own body) is opposed to the personal ' $I$ (summation of roles, properties and competences developed through the active and passive inclusion in social process).$^{68}$ In its turn, modern sociology has focused upon intranslatability between $\mathrm{Sx}$ and Sy in a more explicit way (in a sophisticated formulation of Thomas Luckmann, subjective meaning of action does not overlap with its objective meaning-lessness). ${ }^{69}$ Alas, in all generalist approaches to the problem it is observed from the bird's view, with the sight often glossing over those very issues that make the whole inquiry sensible.

In contrast, Ludwig Wittgenstein has declared the opposition between propositions and demonstratives to be the crux of philosophy: in principle, this distinction could be seen as an internal affair of language (symbols vs. indexes), but the philosopher specifically pointed out that 'showing', unlike 'expressing by a proposition', does not happen within language. ${ }^{70}$ In the course of his checkered philosophical career Wittgenstein returned at least thrice to the meaning of ' $I$ ', each time presenting the contradistinction between $S x$ and $S y$ differently. The opposition between the "subjective" ('I think, that $X$ / 'I hear $Y^{\prime}$ / ' I have pain in my teeth' I 'I try to lift my arm' / 'I think that $Z$ ') and the "objective" ('My hand is broken' / 'I have a dent on my head' / 'The wind blows in my hair) use of the first-person pronoun is the most "logocentrical" version of $S$ in Wittgenstein's works because to its reductionist and formalist traits: whereas the disparity between $S x$ and $S y$ is largely limited to a grammatical

${ }^{66}$ Henri Bergson. Essai sur les données immédiates de la conscience (1888). Paris, 1997, p. 93-104.

${ }^{67}$ Herhard Simmel. Individualismus (1917). - Gerhard Simmel. Gesamtausgabe. Band 13. Frankfurt am Main, 2000, S. 300. Simmel is quite explicit in presenting his theory as a dialectic overcoming of the schism between "formal 'I'" and 'acting personality" inherent in Kant's philosophy (Georg Simmel. Kant und der Individualismus. - Georg Simmel. Gesamtausgabe. Band 7. Frankfurt am Main, 1995, S. 280).

${ }^{68}$ Jan Assmann. Das kulturelle Gedächtnis. Schrift, Erinnerung und politische Identität in frühen Hochkulturen. München, 1997, S. 130-133.

${ }^{69}$ Thomas Luckmann. Persönliche Identität, soziale Rolle und Rollendistanz. - O. Marquard und K. Stierle (Hg.). Identität: (Poetik und Hermeneutik. Bd. VIII). München, 1979, p. 306.

70 «Now I'm afraid you haven't really got hold of my main contention to which the whole business of logical propositions is only corollary. The main point is the theory of what can be expressed by propositions, i.e., by language (and, which comes to the same thing, what can be thought) and what cannot be expressed by propositions, but only shown; which I believe is the cardinal problem of philosophy». (Ludwig Wittgenstein. [Letter to Bertrand Russell from August 8, 1919]. - Ludwig Wittgenstein. Cambridge Letters. Oxford, 1995, p. 124). 
difference between demonstrative and possessive pronouns, the thinking agens (endowed with general (symbolic?) code-reference and infallible self-knowledge) is opposed to the observing patiens (charecterized by individualized (indexical?) self-reference and fallibility). ${ }^{71}$

Abstracting from Wittgenstein's classification criteria, one could notice in his parallel rows of examples a noticeable tendency of opposing individual-driven actions ('I think'/ 'I hear' / 'I try' / 'I feel]) to propositions pertaining to the same individual (which plays well with infallibility / fallibility difference), but this vaguely discernible contrast is a far cry from a full-blown opposition performance / proposition.

The next pair of utterances ('Only I know what I can see' vs. 'Only I know that I am colorblind') seems to combine a heterogeneous pair of a dispositional modal judgment('I can see $X$ ) and a proposition ('I am color-blind) with a second-order analytical presentation of selfreflexivity which, together with affirming its self-knowledge, denies - on the given occasion its transparency to any other bearer of social identity ('I, and only 'I', know Y). ${ }^{72}$ This isolationism fares well with Wittgenstein's occasional denials of code-reference in ' $I$ ' (see above), but still makes a puzzling impression. The careful choice of examples, describing one and the same setting, seems to be ideally suited for contrasting the self-perception of ' $I$ ' (a performance inaccessible to others directly) and its social categorization (a proposition defining social identity through a commonly accepted social symbol): this is why the radical selfreferentiality of ' $I$ ' feels much more in place in the first case than in the second. Again, the documentation on $S x$ and $S y$ seems to be making a stronger case for their unlikeness than the cursory interpretation of this data does.

It is the third, most exacting approach to doubleness of ' $I$ ' that leads Wittgenstein to transgressing the boundaries of language (or, better to say, communication in general) and comprehend social identity as a unity of language and action: this time, the opposition between $S x$ and $S y$ is presented by a minimal pair ('I observe pain' vs. 'I feel pain) which contributes to the meticulousness of analysis. ${ }^{73} \mathrm{As}$ in the previous case, Wittgenstein focuses on the difference of languages $x$ and $y$, holding 'I observing $X^{\prime}$ and 'I feeling $X$ ' to be mutually untranslatable. As feeling and observation here are both sensual activities of the same subject, one may gather that their separation is based on the variance of immediacy (and intersubjectivity) in a self-referential process. In fact, self-observation of a pained subject is normally confined to iconic signs of secondary evidence (such as face expression or skin color), displayed in living world and open to all observers on the same terms (except for obvious disadvantages for the subject-perceiving-itself-as-object discussed on many occasions before). In contrast, self-feeling of a pained subject is transmitted through immediate contact between observed self (receptors) and observing self (spinal cord): whereas this immediacy necessarily presupposes the use of indexical signs (pain receptors being such), the process takes place within the body and cannot be called self-reference in a social sense. Accordingly, the minimal pair produces the maximal divergence between the disparate facets of $S$ :

\footnotetext{
${ }^{71}$ Ludwig Wittgenstein. Preliminary Studies for the "Philosophical Investigations" Generally Known as the Blue and Brown Books (1933-1934). Oxford, 1964, p. 35-36.

72 Ludwig Wittgenstein. 'Bemerkungen über die Farben' (1951). - Ludwig Wittgenstein. Werkausgabe. Band 8. Frankfurt am Main, 1989, S.30.

${ }^{73}$ Ibidem, S. 24.
} 
whereas the sentence 'I observe pain' does not even differentiate between self- and other reference and in this sense demonstrates the total conformity between its self-reflexivity and the code-reference of its meaning (one could effortlessly shift from 'I observe my pain' to 'He observes my pain'), the statement 'I feel pain' excludes this conformity in principle: every attempt to connect its subject to its predicate in a non-reflexive way generates nonsense ('I feel his pain' is equally impossible as 'He feels my pain ).

And yet Wittgenstein tries to bridge the gap between the extremes of $S$ in a second statement by asking himself how the meaning of 'I feel pain' could be materialized and transmitted from the speaker to another inhabitant of a social world. His piercing (in all sense of the word) answer - to prick the second person with the nail that caused the pain of the first - solves problem only partially (pain sensitivity varies).$^{74}$ But it brings the discussion of social identity on a new level precisely by locating the core of social identity between word and action, performance and proposition. In its invisible extreme, the self-reflexivity of social identity is not social: the indexical relation between its receptors and its spinal cord is not available to anyone in a social world. However, this internal relation is projected outside as a pure activity of a closed, reasonably stable living system which hidden self-referentiality is taken for granted by others - otherwise the analogy sought by Wittgenstein simply would not take place.

Unlike Wittgenstein, his distant follower John Austin has never drawn in his analysis a clear line between words and actions: so it was only natural for him to treat at least some ' $I$ ' utterances as unities of performance and proposition. In a way, Austin's theoretical program was even more ambitious than Wittgenstein's: he was not only prepared to consider utterances immediately affecting social life on a pair with propositions, but made them a centerpiece of his doctrine. On the other hand, Austin was reluctant to ban such phenomena from the sphere of linguistic analysis, and the result of this reluctance was the development of "speech acts theory", which greatly increased the attention to social factors of communication in the analysis of meaning. Even so, Austin's binary oppositions, unlike Wittgenstein's pairs, were initially aimed at clear-cut separation between worded actions and words proper: only the failure to achieve this delimitation, it seems, lead him to the idea of dialectical interplay of performative and propositional aspects in the semantics of each utterance (identifications included).

Remarkably, all Austin's examples of sentences "presenting certain actions" (as opposed to sentences that "could be true or false") are complex enough to disprove any simple demarcation of performantive semantics of $S$ from the propositional one. ${ }^{75}$ The simplest examples ('I bet you sixpence it will rain tomorrow' / 'I give and bequest my watch to my brother') shows first-person personal pronoun to be a junction of the general indexical reference to the speaker, and the commitment expressed in a specific form: the fact that the speaker is alive and well, suggested by his ability to utter 'I', is sufficient to suppose his ability to act (for example make promises). ${ }^{76}$ The somewhat trickier sentence ('I name this ship the Queen

\footnotetext{
${ }^{74}$ Ibidem, S. 24.

${ }^{75}$ John Austin. How to Do Things With Words. (William James Lectures delivered at Harvard University). Oxford, 1965, p. 5-6.

${ }^{76}$ Op. cit., p. 7-8.
} 
Elisabeth) hints at a multilayer structure of propositional semantics of $S$, with the codereference of ' $I$ playing a critical role. In fact, unless someone's ambition to baptize ships, expressible in a proposition 'I am the person eligible to name ships', is legitimized in a form of a symmetrical third-person reference ('He is the person eligible to name ships'), the action would not have performative semantics since there will be simply no interaction partners around to support this individual claim. Finally, it is the third and most convoluted example (the bride's positive answer at a wedding ceremony) that seems to cut to the core of the social identity. In this case, the connection between code-reference and self-reflexivity is even more complex than in the previous example. Since Austin did not insist on the specific wording of this speech act, having at some point discarded 'I $d o^{\prime}$ ' as situationally wrong but unable to correct the lectures' text), one may guess that the actual form of the utterance is paradoxically restricted to any affirmation indicating in a single swoop the presence of the actual speaker and the start of his action (dictated, it should be noted, by rigid interactional circumstances that basically leave no choice to the "actor"). The fact that this indication may do without direct (' $I$ ) or indirect (a corresponding predicate) symbolic self-reference, seems to identify the process of speaking as the main reflexive instance in identifications, whereas the role of pronoun as a sign is reduced to confirming symmetry of social identity on the levels of signified (my ' $T=$ ' $I$ ' of the interaction partner) or signifier (my ' $I$ ' = your 'You'), for which, as this example shows, no phenomenal presence is necessary.

Despite this strong suggestions of complementarity between performance and proposition in the structure of $S$, John Austin attempts at first to single out the specific group of performative utterances, which he further subdivides into 'explicit performatives' executing action in unequivocal grammatical terms ('I promise to come tomorrow), and 'implicit performatives' where acting takes place only if the utterance is supported by appropriate intonation, attribute, or interaction context ('I certainly come tomorrow). ${ }^{77}$ Yet he is forced to admit that contextual factors may counteract the verbal semantics of such utterances to the extent that makes the discrimination between 'performative' and 'constative statements' a hopeless task. ${ }^{78}$ Hence in Austin's latter classification every speech act is a resultant force of 'locutionary' (grammar), 'illocutionary' (type of action) an 'perlocutionary' (effect) tendencies, which, in turn, provokes redefinition of 'constatives' and 'performatives' as mere emphases in ' $I$-utterances rather than their separate forms. ${ }^{79}$ Confirming indivisibility of word and action in social identity, these results seem to provide a much better description of the examples chosen by Austin himself to present the gist of his theory. Having demonstrated complementarity of performance and proposition in ' $I$ 'statements, Austin eo ipso completed synthesis of philosophical studies of self-reference and linguistic studies of first-person pronouns with the social theory of identity. Hence his arguments provide a good starting point for attempting a description of this complementarity.

\footnotetext{
${ }^{77}$ Op. cit., p. 99-101.

${ }^{78}$ Op. cit., p. 130.

${ }^{79}$ See Searle's succinct summary: "A man who says 'I (hereby) promise not only promises but says he does" (John Searle. Speech Acts. An Essay in the Philosophy of Language. New York, 1978, p.68).
} 
IV. Social Identity as Paradox: Dialectics of Negative Sub-Identities.

\author{
MOTTO: Social identity $(S)$ has a solution - albeit a problematic one. \\ Structure of $S$ : \\ $S y \neq S \mathrm{x} \neq N x ; S=S x \mathrm{v} y$. \\ Relation Between Self-Reflexivity and Code-Reference: \\ Complementarity $(S x \mathrm{v} S y)$. \\ Problems: \\ Impossibility to define Social Identity in a single utterance.
}

We have seen earlier that the idea of personal identity as a coin with two sides unavailable to each other directly and perhaps indescribable in a single language, has been developed and subsequently refined in French materialism, German transcendental idealism and British analytical philosophy before it was adapted to social sciences in speech acts theory. Still, the crucial question of how $S$ maintains its unity and stability despite heterogeneity of its constitutive elements $S x$ and $S y$ has never been sufficiently answered. The most refined reconstructions, provided by Fichte and Schelling, restrict the duplicity of the subject to internal dialectics of its self-cognizing consciousness and treat individual's body as one of the predicates of the formal ' $I$. In this perspective, the most pressing issues pertaining to the semantics of ' $I$ are out of view. On the one hand, the languages $x$ and $y$, if not directly translatable, differ only in referring to $S$ from the diametrically opposite (and therefore mutually predictable) grammatical standpoints ('subject' vs. 'object'). On the other hand, selfreflexivity, detached from both spoken ' $I$ and speaking body, and therefore no longer immediate and singular (indexical), becomes compatible with code-reference: absorbed by its anaphoric semantics, the first-person pronoun perpetuates the unstoppable growth of the meta-field of identity ('I am (I am (I am... ) )), eroding its social footing with same speed as it appears to cancel out its subject-object differences on ever higher levels of self-consciousness.

In their turn, the models of personal identity proposed by Wittgenstein and Austin seem to reenact its existence in a social world (rather than model its immanent development): while the former brings the individual's body into play, presenting pre-social, intracorporeal self-reference (human pain receptors to human brain) as a variation of immediate self-reflection of $S$, the latter puts individual in the midst of societal interaction, making him produce commitments on the basis of social norms. The obvious strength of both approaches lies in materialization of Schellng's concept of "soaring" ' $I$ ' by exposing heterogeneity of $S x$ an $S y$ as a complementarity of performance and proposition informing social existence of personal identity. At the same time the details of this indivisible unity are not drawn in details, because Wittgenstein is more interested in differentiations and Austin a priori takes words for actions and entrusts their differentiation to the atomized social context.

However, the description of dichotomy that keeps the duality of $S$ together cannot be somehow added post factum to the theory of social identity simply because in this case the meaning of ' $I$ in social communication would remain an unsolvable contradiction. It is apparent that a simple turn-taking or even code-switching is not helpful: impossibility to 
ascertain a stable modality and logical structure of the ' $T$ '-utterance shows that on the threshold of performance and statementce there is no such point of intersection from which both $x$ and $y$ could be deciphered. ${ }^{80}$ If $x$ is called "sign system" (as any language is), than $y$ should be something irrelative to signs (without being an absolute negation of semiosis), and if $y$ is called "activity", then $x$ should be related to the individual irrespectively from his or her state (without necessarily playing the role of passive, unchangeable object).

The following table suggests a possible formalization of relations between Sx an Sy, with examples (underlined) following lemmas:

1. Social identity $S$ can be expressed either by social performance $S y(\operatorname{I}$ am $X)$ or by social proposition $S x$ (' $T$ ' is 'X).

2. Sy expresses social identity by means of reflexive bodily activity including both semiotic (indexical self-pointing by gesture, voice or handwriting) and non-semiotic (deliberate movement) means. The person who says, gestures or otherwise signals 'I feel pain' appears as a single living being to himself and others.

3. Sx expresses social identity by means of intersubjectively coded communication (including symbols and icons). The person who says, gestures or otherwise signals 'I feel pain' is identified by himself and others as an individual ('I) whose state is characterized by words ('feel pain'), images (face expression of a pained person) or other kinds of signs used in everyday communication.

4. The meaning of $S y$ is always the same ('This is here and now $)^{81}$, but it is perceived differently by speaker and addressee. From the position of speaker, this meaning expresses organizational closeness of the autopoetic system, which stabilizes identity to prevent its dissipation (self-reflexivity). From the position of the addressee, this meaning expresses the living state (a specific kind of spatial and temporal unity and mobility) of a certain being which makes the latter a potential partner in communication. ${ }^{82}$ The person who says, gestures or otherwise signals 'I feel pain' communicates his presence to others, although his meaning of presence (being in some state) is different from his communication partner (being a separate unity).

${ }^{80}$ See: Heinz-Dieter Heckmann. 'Wer (oder was) Ich bin? Zur Deutung des intentionalen Selbstbezuges aus der Perspective der ersten Person singularis'. In: Bertran Kienzle, Helmut Pape (eds). Dimensionen der Selbst: Selbstbewusstsein, Reflexivität und die Bedingungen der Kommunikation. Frankfurt am Main, 1991, p. 81; Harold Noonan. Identity and the First Person. - Cora Diamond (ed.). Intention and Intentionality: Essays in Honor of Gertrude E. M. Anscombe. Ithaca, 1979, p. 61; Norman Malcolm. Whether 'I' is a referring expression. - Idem, p. 19 ; Udo Tietz. Grenzen der 'Wir': Eine Theorie der Gemeinschaft. Frankfurt am Main, 2002, S. 212-213. See the same problem in linguistic perspective: George Lakoff. Sorry, I am Not Myself Today: The Metaphor System for Conceptualizing the Self. - Gilles Fauconnier, Eve Sweetser (eds.). Spaces, worlds and Grammar. Chicago, 1996, p. 51; Sidn Shoemaker. Self-Reference and Self-Awareness. - Quassim Cassam (ed.). Self-Knowledge. Oxford, 1994, p.81.

${ }^{81}$ See: G. E. M. Anscombe. 'The First Person'. In: Samuel Guttenplan (ed.). Mind and Language. Oxford, 1975, p. 60; Helmut Plessner, Der kategorische Konjunktiv: Ein versuch über die Leidenschaft (1968). - Helmut Plessner. Gesammelte Schriften. Band VIII. Frankfurt am Main, 1983, S. 338-339;

${ }^{82}$ On spatiotemporal unity as the external criterion of identity see: Ernst Tugendhat. Op. cit., S. 77-78. The conflation of the speaker's and addressee perspectives in the meaning of Sy results in modern philosophy in the revival of Lockian view of "mental continuity" as a precondition for survival (see: David Lewis. Survival and Identity. - Amélie Oksenberg Rorty, (ed.). The Identities of Persons. Berkeley et al., 1976, p. 17). 
5. The meaning of $S x$ is always a variable of its predicate ' $X$ ', but these fluctuations are perceived consensually by speaker and the addressee because both terms of the proposition are defined before the actual communicative exchange on the basis of valid intersubjective agreements (code-reference). In the utterance or gesture ' $I$ ' am sick' ' $I$ stands for an individual conspecific (equal in interaction), and 'sick' stands for a certain attribute of such an individual that would appear equal to both communication participants. ${ }^{83}$

6. Sy cannot multiply. In the utterance 'We are sick' there is only one meaning 'This is here and now' both for the speaker and for the addressee. ${ }^{84}$

7. Sx can multiply both in its signifier and in its signified. The utterance 'We are sick' can have infinite number of meanings ' $I$ ' is 'sick'. The sentence ' $I$ ' think that I think that I think that... may contain an infinite number of ' $I$ ' is 'thinking that $X^{\prime}$ simple sentences. ${ }^{85}$

8. Sy is a pure performance with no internal teleology (like grammatical subject-object segmentation, logical subject-predicate segmentation or simple narrative [before lafter] linearity). Although $S x$ occurs in time, its (reflexive) meaning is simultaneous: the temporality of speech means 'being alive' and not 'proceeding from ' $I$ ' to its predicate').

9. $S_{x}$ is a pure proposition which meaning is determined by the logical (grammatical) following from subject to predicate/object. Although $S y$ has an indivisible meaning, it is determined by the progression from the coded reference to agens to the coded reference to patiens.

10. Sy negates its structure in existence. The meaning is communicated by the evolving activity (staying alive) of speaker, whereas its codified element (uttering 'I am alive) plays no semantic role.

11. Sx negates its existence in structure. The meaning is communicated by the words I feel well' whereas the changes occurring during pronouncing (or writing) this sentence play no semantic role.

12. Social identity $S$ can never be $S x$ and $S y$ at the same time, but must necessarily be either one at a certain period of time, must begin with $S y$ and continue with $S x$, and cannot be just one throughout the whole period of its existence. A living being that had never used ' $I$ in a coded proposition, has no social identity yet, but may have one in the future. ' $T$ in

${ }^{83}$ In this sense the third-person perspective, chosen by Frege, is unstructive: "Wenn er also sagt 'Ich bin verwundet worden', muss er das Ich in einem Sinne gebrauchen, der auch anderen fassbar ist, etwa in dem Sinne von 'derjenige, der in diesem Augenblicke zu mir spricht'" (Gottlob Frege. Logische Untersuchungen. Erster Teil. Der Gedanke. (1918). - Gottlob Frege. Kleine Schriften. Hildesheim, 1990, S. 350.

${ }^{84}$ This seems to me a good argument for caution in postulating collective intentionality, 'we'-thinking etc.. (see the latest representative volume: Hans Bernhard Schmid, Katinka Schulte-Ostermann, Nikos Psarros (eds.). Concepts of Sharedness: Essays on Collective Intentionality. Heusenstamm bei Frankfurt, 2009).

${ }^{85}$ The homonymy of 'I' in such subordinating syntactic constructions in spite of its obvious semantic dissimilarity is an important linguistic mechanism of code-reference invoked by Hegel ('Ich, das Gleichnamige, stoße mich von mir selbst ab' - Georg W. F. Hegel. Phänomenologie des Geistes.., S. 135). The contrast between the semantic growth of 'I' and its unchanging signifier is vividly portrayed by Dante who says to his noble forefather Cacciaguida 'voi mi levate si ch'i' son più ch'io': the deliberate semantic contradiction ("I am more than I") is offset by the metaphor of spiritual upswing from the earthly individual 'I' to its sublime familial version (Dante Alighieri La Divina Commedia (1321). Milano, 1965, p. 151). 
the text for which no performance could be ascertained has no social identity and will never have it. ${ }^{86}$

At the end, it seems reasonable to try to briefly inscribe the presented outline of social identity into a larger social systematics. Heterogeneity and complementarity of $S$ stem from its intermediate position in the hierarchy of dissipative systems: being squeezed between living organism and society, social identity should beware the independence of its owner together with enabling his participation in social interaction on reasonable terms. It seems like the first goal is achieved by the performativity of social identity which keeps its denotative contingency in check: the fact that the meaning of $S y$, oscillating between two extreme communicative states ('life' and 'death), does not depend on the semiotic structure of $S$, turns self-reflexivity into a stronghold of individual existence in a social world. The second goal, in its turn, is fulfilled by the propositional structure of social norms, which allows for an abstract use of communicative means: as long as the meaning of ' $I$ ' in a statement can be regulated independently of its concrete speaker in a specific speech act, the universality of a code will not be threatened by its individual users. ${ }^{87}$ Last but no least, the asymmetry between $S y$ and $S x$ rules out the possibility of a fake social identity - with no footing in a natural world - such as "transcendental subject" of Husserl or a pseudo-collective 'We' of totalitarian ideologues. Seen in this perspective, the presented outline of social identity as a complementarity of performance and proposition may have practical applications in social history which, however, remain beyond the scope of this text. ${ }^{88}$

\footnotetext{
${ }^{86}$ In some way this temporal hierarchy corresponds to the movement of Schelling's ' $I$ ' from the sole prepropositional self-consciousness to its coexistence with propositional double (see: Roswitha Staege. "...das Ich selbst ist die Zeit in Tätigkeit gedacht”. Marburg, 2007).

${ }^{87}$ This regulation of a social system through the symmetrical relations between the codified self-references, abstracted but not detached from their reflexive functions has been in part suggested by Helmut Plessner in the article cited above. It may answer the concerns of Luhmann's critics who lamented the absence of communicators in his theory of self-regulating social systems (see, for instance: Siegfried J. Schmidt. Kognitive Autonomie und Soziale Orientierung: Konstruktivistische Bemerkungen zum Zusammenhang von Kognition, Kommunikation, Medien und Kultur. Frankfurt am Main, 1994, S.78)

${ }^{88}$ See: Kirill Postoutenko. Between "I" and "We": Studying the Grammar of Social Identity in Europe (19001950). - Journal of Language and Politics, 2009, Vol.8 (2), 195-222.
} 